\author{
Vasyl Shevchuk, Olexandra Macyak and Ludmila Babyak
}

\title{
OBTAINING OF HIGH-OCTANE COMPONENTS BY CONVERSION OF HYDROCARBON RAW MATERIAL ON HIGH-SILICA ZEOLITES
}

Received: April 28, 2007

\author{
Lviv Polytechnic National University \\ 12 Bandera str., 79013 Lviv, Ukraine
}

\begin{abstract}
Catalytic conversion of gaseous alkanes, alkenes and gasoline fractions over high-silica zeolites of ZSM-5 type has been studied. The optimal condition for the production of high-octane components of motor fuels over $\mathrm{ZVM}+2 \%$ mass of $\mathrm{Zn}$ modified catalyst and nonmodified catalyst ZVN have been established.
\end{abstract}

Keywords: zeolite-containing catalyst, arenes, isoalkanes, petrol fractions, catalyzate.

\section{Introduction}

Development of combustion engines and increase of ecological requirements to petrol entailed the necessity in high-octane components of motor fuels. Today highoctane components are produced using reforming, alkylation and isomerization, which are power-consuming and capital-intensive processes. Therefore, the development of new processes of high-octane components production including processes with alternative raw material is of great importance.

The number of foreign firms carries out researches of hydrocarbon gases conversion over high-silica zeolites. Industrial processes of aromatic hydrocarbons production are implemented $[1,2]$. In Ukraine the processes of highoctane components production by catalytic conversion of hydrocarbon raw material over high-silica zeolites are absent.

\section{Experimental}

At the Department of Chemical Technology of Oil and Gas Refining of Lviv Polytechnic National University catalytic conversion of gaseous alkanes, alkenes as well as petrol fractions of primary and secondary origin over high-silica zeolites of ZSM-5 type has been investigated. Zeolite catalysts based on zeolites of ZVM and ZVN types are produced at Angarsk catalyst plant. Physico-chemical characteristics of above mentioned zeolites are presented in Table 1.

Table 1

Characteristics of $\mathrm{ZVM}$ and $\mathrm{ZVN}$ zeolites

\begin{tabular}{|l|c|c|}
\hline \multirow{2}{*}{ Index } & \multicolumn{2}{|c|}{ Zeolite brand } \\
\cline { 2 - 3 } & $\mathrm{ZVM}$ & $\mathrm{ZVN}$ \\
\hline Silicate module $\left(\mathrm{SiO}_{2}: \mathrm{Al}_{2} \mathrm{O}_{3}\right)$ & 23 & 26 \\
\hline Specific surface, $\mathrm{m}^{2} / \mathrm{g}$ & $400-450$ & $420-500$ \\
\hline $\begin{array}{c}\text { Static adsorption capacity, } \mathrm{cm}^{3} / \mathrm{g}: \\
-\quad \text { by water vapors } \\
-\quad \text { by heptane vapors }\end{array}$ & 0.08 & 0.06 \\
\hline $\mathrm{Na}_{2} \mathrm{O}$ content, mass \% & $0.16-0.18$ & $0.17-0.20$ \\
\hline
\end{tabular}

ZVM and ZVN zeolites are differed by their method of preparation and usage of organic additions. ZVM is a high-silica zeolite obtained by crystallization of alumo-silica gels under hydrothermal conditions without organic components. ZVN is a catalyst of the pentasyl class with a very low content of inorganic cation. The essential principle of its synthesis is a considerable cross-linking effect of cation of a strong organic bases, which is able to operate as a compensating cation. Amine alcohols or amines (1,6-diaminehexane, 1,3-diaminepropane, etc.) are organic bases of the catalysts.

ZVM zeolite modified with 2 mass \% of zinc and non-modified ZVN zeolite were used as catalysts. $30 \%$ of the linking agent $\left(\mathrm{g}-\mathrm{Al}_{2} \mathrm{O}_{3}\right)$ was added to $\mathrm{ZVM}$ zeolite for the increase of the catalyst mechanical strength. The industrial ZVN catalyst is used in the processes of petroleum refining and petrochemistry and has the sufficient strength.

\section{Results and Discussion}

The results of researches of catalytic conversion of gaseous alkanes, alkenes and petrol fractions over mentioned catalysts are represented in $[3,4,5,6]$. Aromatic hydrocarbons are main products obtained over ZVM +2 mass $\% \mathrm{Zn}$. Isoalkanes and aromatics are obtained over ZVN.

This work deals with the generalized experimental results of catalytic conversion of gaseous alkenes and petrol fractions over above-mentioned catalysts with the purpose of obtaining motor fuel high-octane components. 
Results of the propylene catalytic conversion over $\mathrm{ZVM}+2$ mass $\% \mathrm{Zn}$ and ZVN are presented in Table 2. Almost complete propylene conversion and high selectivity to liquid catalyzate formation are achieved under experimental conditions. The liquid catalyzate consists of alkanes and arenes. It should be noted that the high selectivity to high-octane components formation is achieved at lower temperatures over ZVN catalyst in comparison with ZVM+2 mass \% Zn. Since over ZVN catalyst with the temperature increase the part of cracking reactions increases as well.

Liquid products obtained at propylene conversion over $\mathrm{ZVM}+2$ mass \% $\mathrm{Zn}$ contain mainly aromatic hydrocarbons. Therefore, at propylene conversion over ZVN catalyst aliphatic liquid hydrocarbons of isometric structure are the main products. The composition of the catalyzate obtained at propylene catalytic conversion over ZVN under optimum conditions, is presented in Fig. 1.

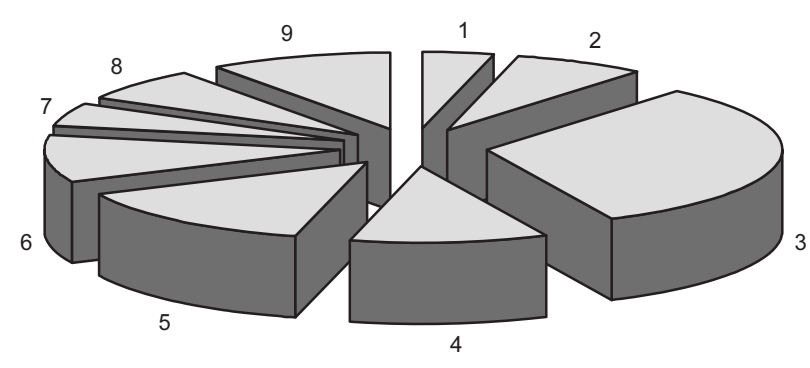

Fig. 1. Composition of catalyzate obtained at propylene conversion

(ZVN catalyst, $\mathrm{T}=623 \mathrm{~K}, \mathrm{~W}=1000$ hour $^{-1}$ )

1 - n-pentane (4\%); 2 - i-pentane $(7 \%)$;

3 - 2,3-dimethylbutane (32\%); 4 - 2,2,3-trimethylbutane

$(11 \%) ; 5-2,2$, -dimethylbutane $(14 \%) ; 6$ - benzene $(10 \%)$;

7 - toluene $(5 \%) ; 8$-xylenes $(7 \%) ; 9-\mathrm{C}_{9+}(10 \%)$
We can see from Fig. 1 that the iquid catalyzate mainly contains alkanes and $\mathrm{C}_{5}-\mathrm{C}_{7}$ isoalkanes, in particular: isopentane with the octane number O.N.= 90; dimethylbutane - O.N. $=95 ; 2,2,3$-dimethylbutane - O.N. $=$ $=101 ; 2,2$-dimethylbutane - O.N. $=96$.

Gaseous products mainly consist of hydrogen, $\mathrm{C}_{1}-\mathrm{C}_{4}$ alkanes and $\mathrm{C}_{2}-\mathrm{C}_{4}$ alkenes. Their total concentration varies from 6 to $8 \%$.

The similar composition of the products is obtained at ethylene and butylene conversion over ZVN catalyst.

Under assigned conditions the modified and nonmodified ZVN catalysts have the low selectivity in the reactions of gaseous alkanes conversion. The liquid catalyzate yield does not exceed $20 \%$ since cracking reactions mainly proceed.

The results of the catalytic conversion of the straight-run petrol fraction and the petrol fraction of the low-level thermal cracking over ZVM+2 mass \% Zn and ZVN catalysts under optimum conditions are represented in Tables 3 and 4, the maximum yield of the high-octane catalyzate is achieved.

As we can see from the tables, the catalyzate obtained at the conversion of the petrol fraction of lowlevel thermal cracking over ZVM+2 mass \% Zn, mainly consists of aromatic hydrocarbons (benzene-toluenexylenes). Under similar conditions aromatics content exceeds the content of arenes in the catalyzate obtained at conversion of straight-run petrol by $30 \%$. Conversion degrees of alkanes and cycloalkanes obtained at low-level thermal cracking are higher in comparison with degrees of similar hydrocarbons of straight-run petrol. It is explained by the fact, that alkenes are active in the aromatization reaction and increase the conversion rate of initial alkanes and cycloalkanes. In other words, the presence of alkenes favors the deeper aromatization of raw material.

\section{Propylene catalytic conversion}

\begin{tabular}{|c|c|c|c|c|c|c|c|c|c|c|c|c|c|c|c|c|c|}
\hline \multirow{2}{*}{ 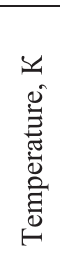 } & \multirow[b]{2}{*}{ 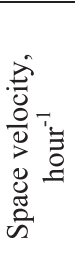 } & \multirow{2}{*}{ 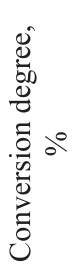 } & \multirow[b]{2}{*}{ 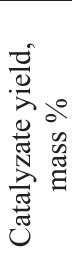 } & \multicolumn{5}{|c|}{ Composition of liquid catalyzate, mass } & \multicolumn{9}{|c|}{ Composition of gaseous products, vol. \% } \\
\hline & & & & 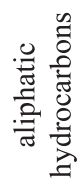 & $\begin{array}{l}\text { : } \\
\text { N } \\
\text { D. }\end{array}$ & 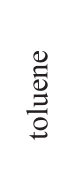 & $\mathrm{C}_{8}$ & $\mathrm{C}_{9}-\mathrm{C}_{12}$ & $\mathrm{H}_{2}$ & $\mathrm{CH}_{4}$ & $\mathrm{C}_{2} \mathrm{H}_{6}$ & $\mathrm{C}_{2} \mathrm{H}_{4}$ & $\mathrm{C}_{3} \mathrm{H}_{8}$ & $\mathrm{C}_{3} \mathrm{H}_{6}$ & 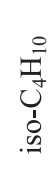 & $\underset{\stackrel{1}{=}}{\stackrel{0}{U_{+}^{+}}}$ & $\underbrace{\infty}_{W}$ \\
\hline \multicolumn{18}{|c|}{$\mathrm{ZVM}+2$ mass $\% \mathrm{Zn}$ catalyst } \\
\hline 773 & 1000 & 96.7 & 66.2 & 3.2 & 21.7 & 45.9 & 26.1 & 3.1 & 47.7 & 10.1 & 5.7 & 3.1 & 27.1 & 2.9 & 2.0 & 1.4 & - \\
\hline \multicolumn{18}{|c|}{ ZVN catalyst } \\
\hline 673 & 1000 & 97.8 & 66.0 & 65.2 & 11.4 & 5.9 & 9.1 & 8.4 & 28.5 & 1.2 & 6.3 & 5.9 & 39.2 & 9.2 & 4.7 & 5.0 & - \\
\hline
\end{tabular}


Conversion of straight-run petrol fraction

(hydrocarbon type content, mass \%: arenes - 10.1; n-alkanes - 31.2; isoalkanes - 37.4; cycloalkanes - 21.3; alkenes - 0.1)

\begin{tabular}{|c|c|c|c|c|c|c|c|c|c|c|c|c|c|c|c|c|c|c|}
\hline \multirow{2}{*}{ 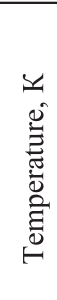 } & \multirow{2}{*}{ 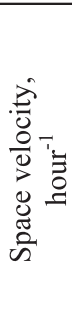 } & \multirow{2}{*}{ 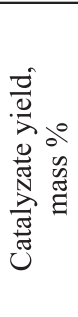 } & \multicolumn{5}{|c|}{$\begin{array}{l}\text { Hydrocarbon type content of } \\
\text { catalyzate, mass } \%\end{array}$} & \multicolumn{8}{|c|}{ Composition of gaseous products, vol. \% } & \multicolumn{3}{|c|}{$\begin{array}{l}\text { Carbon part }(\%) \text { of } \\
\text { initial hydrocarbons } \\
\text { converted into: }\end{array}$} \\
\hline & & & 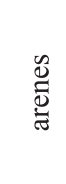 & 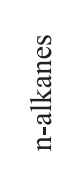 & 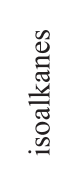 & 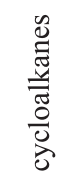 & $\begin{array}{l}\mathscr{E} \\
\stackrel{0}{\sigma}\end{array}$ & $\mathrm{H}_{2}$ & $\mathrm{CH}_{4}$ & $\mathrm{C}_{2} \mathrm{H}_{6}$ & $\mathrm{C}_{2} \mathrm{H}_{4}$ & $\mathrm{C}_{3} \mathrm{H}_{8}$ & $\mathrm{C}_{3} \mathrm{H}_{6}$ & 疍 & 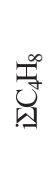 & 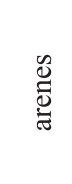 & 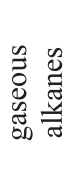 & 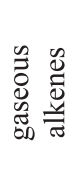 \\
\hline \multicolumn{19}{|c|}{$\mathrm{ZVM}+2$ mass $\% \mathrm{Zn}$ catalyst } \\
\hline 773 & 6 & 68.2 & 28.0 & 12.0 & 35.1 & 22.7 & 2.2 & 24.7 & 3.6 & 3.2 & 9.2 & 31.3 & 12.4 & 14.9 & 0.7 & 23.1 & 3.4 & 72.9 \\
\hline \multicolumn{19}{|c|}{ ZVN catalyst } \\
\hline 673 & 6 & 72.8 & 21.8 & 11.6 & 42.3 & 21.7 & 2.6 & 13.6 & 2.8 & 2.6 & 5.6 & 36.2 & 10.2 & 22.6 & 4.4 & 17.9 & 5.2 & 76.1 \\
\hline
\end{tabular}

Conversion of petrol fraction with unsaturated hydrocarbons (hydrocarbon type content, mass \%: arenes - 13.2; n-alkanes - 32.8; isoalkanes - 27.0; cycloalkanes - 18.8; alkenes - 8.2)

\begin{tabular}{|c|c|c|c|c|c|c|c|c|c|c|c|c|c|c|c|c|c|}
\hline \multirow{2}{*}{ 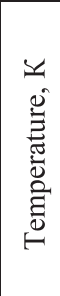 } & \multirow{2}{*}{ 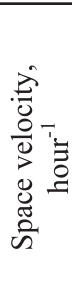 } & \multirow{2}{*}{ 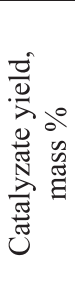 } & \multicolumn{5}{|c|}{$\begin{array}{l}\text { Hydrocarbon type content of } \\
\text { catalyzate, mass } \%\end{array}$} & \multicolumn{7}{|c|}{ Composition of gaseous products, vol. $\%$} & \multicolumn{3}{|c|}{$\begin{array}{l}\text { Carbon part }(\%) \text { of } \\
\text { initial hydrocarbons } \\
\text { converted into: }\end{array}$} \\
\hline & & & 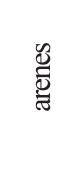 & 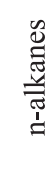 & 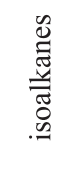 & 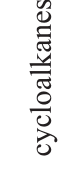 & 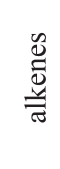 & $\mathrm{H}_{2}$ & $\mathrm{CH}_{4}$ & $\mathrm{C}_{2} \mathrm{H}_{6}$ & $\mathrm{C}_{2} \mathrm{H}_{4}$ & $\mathrm{C}_{3} \mathrm{H}_{8}$ & $\mathrm{C}_{3} \mathrm{H}_{6}$ & 奈 & 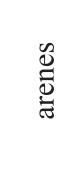 & 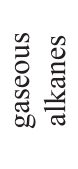 & 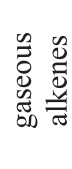 \\
\hline \multicolumn{18}{|c|}{$\mathrm{ZVM}+2$ mass $\%$ Zn catalyst } \\
\hline 823 & 3 & 58.0 & 87.0 & 2.3 & 6.3 & 4.4 & - & 65.0 & 8.7 & 5.4 & 5.0 & 11.4 & 3.2 & 1.4 & 50.8 & 34.6 & 11.4 \\
\hline \multicolumn{18}{|c|}{ ZVN catalyst } \\
\hline 673 & 6 & 70.7 & 42.3 & 9.2 & 24.0 & 20.9 & 3.6 & 14.3 & 0.9 & 2.3 & 5.1 & 36.7 & 5.5 & 35.2 & 37.2 & 53.4 & 5.4 \\
\hline
\end{tabular}

Higher selectivity to arenes formation as well as selectivity to gaseous alkenes formation is achieved at lower temperatures over ZVN catalyst in comparison with those achieved over ZVM+2 mass \% Zn.

At the petrol conversion over ZVN catalyst the aromatic hydrocarbons yield is less, in comparison with their conversion over $\mathrm{ZVM}+2$ mass $\% \mathrm{Zn}$. The catalyzate obtained at straight-run petrol conversion over ZVN catalyst contains $21.8 \%$ of arenas and at the conversion of petrol of low-level thermal cracking $-42.3 \%$. Benzene content does not exceed 4 mass \%.

\section{Conclusions}

The material balance analysis of of certain classes of hydrocarbons conversion reactions shows that alkanes and alkenes are mainly converted over ZVN catalyst with the formation of aromatic hydrocarbons and gaseous products. Conversion degrees of isoalkanes and cycloalkanes are insignificant. Therefore, the catalyzate mainly contains arenas, isoalkanes and cycloalkanes. The content of sulphur-containing compounds decreases in liquid products. 
Thus, the catalyzate with the high content of arenes may be obtained over ZVM+2 mass $\%$ Zn by catalytic conversion of refinery gases containing alkenes and petrol fractions of the secondary origin. The conversion of the same raw material over ZVN catalyst results in obtaining of the catalyzate containing the considerable amount of isoalkanes and cycloalkanes, as well as arenes. Investigated processes may be alternative ones to reforming and isomerization.

\section{References}

[1] Commercial test for "Cyclar Process": Petroleum Times, 1987, 2213, 14.

[2] Tabak S., Krambeck F. and Garwood W.: AIChI J., 1996, 32, 1526.

[3] Babyak L., Dzih I., Abadjev S. and Shevchuk V.: Deponovana DNTB Ukrainy, Kyiv 1993.

[4] Macyak O., Dzih I., Abadjev S. and Shevchuk V.: Ekotehnologii i resursozberegeniya, 1994, 5-6, 27.
[5] Bratychak M., Babyak L., Grushchak V., Macyak O., Shevchuk V. and Abadjev S.: Naftova i gazova promyslovist, 2000, 6, 58 .

[6] Macyak L., Shevchuk V., Abadjev S., Grushchak V. and Babyak L.: Visnyk DU “LP”, 2000, 388, 157.

\section{ОДЕРЖАННЯ ВИСОКООКТАНОВИХ КОМПОНЕНТІВ ПЕРЕТВОРЕННЯМ ВУГЛЕВОДНЕВОЇ СИРОВИНИ НА ВИСОКОКРЕМНЕЗЕМИСТИХ ЦЕОЛІТАХ}

Анотація. Вивчено каталітичне перетворення газоподібних алкенів $і$ алканів та бензинових фракцій на висококремнеземистих иеолітах типу ZSM-5. Встановлені оптимальні умови одержання високооктанових компонентів моторних палив на модифікованих та немодифікованих каталізаторах марок ЦВМ+2\% мас.Zn і ЦВН.

Ключові слова: иеолітвмісні каталізатори., арени, ізоллкани, бензинові фракиії, каталізат. 